\title{
Impact of genital hair removal on female skin microenvironment: barrier disruption and risk of infection, a literature review
}

\author{
Daniel Giovanny Romero-Gamboa* \\ Luis Alfonso Díaz-Martínez** \\ Marta Lucía Díaz-Galvis*** \\ Diana Paola González-Blanco****
}

\begin{abstract}
*5th Year Medical Student. School of Medicine. Faculty of Health. Industrial University of Santander. Bucaramanga. Colombia.
** MD Pediatrician. MSc Epidemiology. School of Medicine. Faculty of Health. Industrial University of Santander. Bucaramanga. Colombia.

*** Bacteriology and Clinical Laboratory. MSc Medical Sciences. PhD Biomedical Sciences. Group of Immunology and Molecular Epidemiology. Faculty of Health. Industrial University of Santander. Bucaramanga. Colombia.

****4th Year Medical Student. School of Medicine. Faculty of Health. Industrial University of Santander. Bucaramanga. Colombia.

Correspondence: Sr. Daniel Romero Gamboa. E-mail: daniel.rg2195@gmail.com. Address: Calle 19 \# 32-23. Bucaramanga. Colombia. Tel: 3166993542
\end{abstract}

\section{Abstract}

Genital hair is one of the secondary sexual traits that marks the beginning of puberty; its removal has been part of human culture since ancient times. This practice may lead to modifications in vaginal microbiome with potential repercussions on skin health and balance. We conducted a narrative review with the purpose of describing normal skin microbiota, its impact under microenvironment changes and genital hair removal. Menses, pathological conditions and pubic hair removal may alter vaginal microbiota, being the latter of special relevance giving the risk of hair microtrauma, irritations and potential spread of infectious agents. MÉD.UIS.2019;32(3):27-33

Keywords: Female Genitalia. Microbiota. Hair Removal. Corynebacterium. Staphylococcus.

\section{Impacto da depilação genital no microambiente da pele feminina: ruptura de barreira e risco de infecção, uma revisão da literatura}

Resumo

O cabelo genital é um dos traços sexuais secundários que marcam o início da puberdade; sua remoção faz parte da cultura humana desde os tempos antigos. Essa prática pode levar a modificações no microbioma vaginal com possíveis repercussões na saúde e equilíbrio da pele. Realizamos uma revisão narrativa com o objetivo de descrever a microbiota normal da pele, seu impacto nas alterações do microambiente e na remoção de pelos genitais. A menstruação, as condições patológicas e a remoção de pelos pubianos podem alterar a microbiota vaginal, sendo esta última de especial relevância dando o risco de microtraumatismo capilar, irritações e potencial disseminação de agentes infecciosos. MÉD.UIS.2019;32(3): 27-33

Palavras-chave: Genitália Feminina. Microbiota. Depilação. Corynebacterium. Staphylococcus.

Impacto de la depilación genital en el microambiente de la piel femenina: interrupción de la barrera y riesgo de infección, una revisión de la literatura

Resumen

El vello genital es uno de los rasgos sexuales secundarios que marca el comienzo de la pubertad; su eliminación ha sido parte de la cultura humana desde la antigüedad. Esta práctica puede conducir a modificaciones en el microbioma vaginal con posibles repercusiones potenciales en la salud y el equilibrio de la piel. Realizamos una revisión narrativa con el propósito de describir la microbiota cutánea 
normal, su impacto bajo los cambios del microambiente y la depilación genital. La menstruación, las condiciones patológicas y la depilación púbica pueden alterar la microbiota vaginal, siendo esta última de especial relevancia dado el riesgo de microtraumatismos, irritaciones y posible propagación de agentes infecciosos. MÉD.UIS.2019;32(3): 27-33

Palabras clave: Genitales Femeninos. Microbiota. Remoción del Cabello.

¿Cómo citar este artículo?: Romero-Gamboa DG, Díaz-Martínez LA, Díaz-Galvis ML, GonzálezBlanco DP. Impact of genital hair removal on female skin microenvironment: Barrier disruption and risk of infection, a literature review. MÉD.UIS.2019;32(3):27-33. doi: 10.18273/revmed.v32n32019004

\section{Introduction}

Genital hair is one of the secondary sexual traits that alongside with thelarche marks the beginning of puberty'. From a social and sexual perspective, it is believed that pheromonal signaling, through dense apocrine sweat glands in the pubic area, serves as a communication method to improve attractiveness ${ }^{2}$. Its biological functions include: pheromone dissemination through apocrine glands, protection of genitalia against cloth friction, and the control of genital moisture ${ }^{2,3}$. Recent studies have associated the presence of pubic hair with greater capacity to trap and stop microorganisms, as well as the production of bacteriostatic peptides from sebum produced by hair follicles ${ }^{4}$.

On the other hand, body hair removal has been a practice inherent to the human since the beginning of time ${ }^{1}$, overstepping many cultures and periods of human history ${ }^{5}$, being evidenced in ancient Egypt and Greek engravings ${ }^{6}$. It has been a notably increasing practice in western countries for diverse reasons: hygienic, aesthetic, and/or erotic 7 . The most common methods of genital hair removal are shaving and waxing 8 . In Colombia, a recent study reported a prevalence of genital hair removal in women of $57,9 \%$ (IC 43,7\%-70,8\%; P<0,001) 7 .

In the case of Colombia, a recent study which intended to establish the prevalence of genital hair removal in 1964 necropsies, registered a prevalence of genital hair removal between men of 31,1\% and women of $57,9 \%$. Although it has become a relatively mundane, normalized, unquestioned part of many men and women's lives ${ }^{5}$, as with any practice it is subject to adverse health consequences; ranging from less serious complications such as mechanic or infectious folliculitis and contact dermatitis ${ }^{6}$ all the way to genital burns from waxing, skin irritation, vulvar and vaginal irritation and infection, and spread of sexual transmitted infections 9 . Another study in Colombia during 2015 reported a prevalence of clinical problems of 10,4\% (IC95\% 8,3-13\%) related to genital hair removal which were also seen in association with one out of ten individuals over fourteen-years-old who sought medical attention by conditions not related with genital skin disorders. Out of ten individuals, six went through infectious processes, three attributed to trauma and one by alterations that underwent cutaneous symptoms ${ }^{6}$. One plausible and modifiable factor that may change the vaginal microbiome is the presence of pubic hair.

For the above, we propose to conduct a narrative review regarding the normal skin microbiota and its impact under genital hair removal and microenvironment changes, accessing its possible risk of disbalance and disease.

\section{Method}

A specialized literature search was carried out, during the period from March to May of 2018 in PubMed, ScienceDirect and Scielo databases, using the following search words: female genitalia, microbiota, hair removal as MESH terms and genitales femeninos, microbiota, remoción del cabello as DECS terms. Inclusion criteria included articles that discussed the relationship between the removal of genital hair and the impact on the female genital microbiota, as well as the normal and abnormal bacterial flora in the female genitalia. Articles that did not have women as a population study were excluded. A total of 69 articles were initially obtained, of which 39 were finally included for the elaboration of the article, articles that discussed changes in physiological properties (transepidermal water loss, changes in $\mathrm{pH}$, among others) in relation to microbiota were not included because it did not correspond to our proposed objective. 


\section{The normal female genitalia and normal skin microenviroment}

As with any portion of this large organ of the integumentary system ${ }^{10}$, vulvar skin undergoes a series of physiological changes over time which altogether have an impact on its mechanical properties"1. Morphology and physiology of the vulva and vagina change over a lifetime. Newborns exhibit the effects of residual maternal estrogens; labia majora appear thick and labia minora seem well developed. As the estrogen levels dissipate, the vaginal epithelium becomes thinner. Pubertal changes are induced by adrenal and gonadal maturation. Pubic hair growth proceeds in five stages and as estrogen production rises, vaginal epithelium thickens, cervix and vagina increase in size and fat begins to establish alongside the mons pubis and labia majora. During reproductive years, the menstrual cycle is already established and plays a key role in vulvar and vaginal changes. During mid-cycle, estrogen keeps leading the vulvar epithelial rise, glycogen content and parakeratosis of the vaginal epithelium. Pregnancy also becomes a significant variable, as an increase in total blood volume heightens the coloration of the vulva and vagina. Venous distensibility rises in association with progesterone levels. Delivery represents a change in morphology and dimensions of the vaginal tract, which are generally reversed over the next six weeks. Following menopause, pubic hair becomes scarce, the labia majora loses subcutaneous fat, labia minora, vestibule and vaginal mucosa undergo atrophy, vaginal secretions decrease, tissue loses its thickness and becomes predisposed to irritation and susceptible to infection ${ }^{10}$.

\section{Normal genital microbiome}

An abundant and diverse community of microorganisms including bacteria, fungi and virus inhabit the human skin ${ }^{12}$. The human microbiome is almost as unique as a person's own genome ${ }^{13}$. An estimated of over 100 distinct species, making up a total of 1 million microorganisms, colonize each square centimeter of human $\mathrm{skin}^{14}$. The terms normal skin flora and commensal skin flora are used to describe those microorganisms that are usually found in the skin of healthy individuals ${ }^{15}$. Bacterial composition is dependent on the physiology of the skin site, with specific bacteria being associated with moist, dry, and sebaceous microenvironments. Different body habitats have different microbiome compositions ${ }^{13,16}$. These precise environment characteristics allow bacteria to produce extracellular substances that result in networks (or biofilms), which enable multicellular functions, differentiation and community-like living ${ }^{17}$. Anatomical sites with partial occlusion (such as axilla and perineum) yield a greater density of microorganisms than less occluded areas (legs, arms and trunk) ${ }^{18}$.

The vulvar structure, acidic vaginal $\mathrm{pH}$ (3.8-4.4 in reproductive age), vulvar $\mathrm{pH}(3,7-4,7)$ and vaginal discharge altogether protect the genital tract from infection ${ }^{19}$. The tract has a variety of habitats that are determined by differences in epithelium, moisture content, density of glands, degree of occlusion, proximity to other densely populated sites, among others. Vulvar folds are sites of microbial collections; balance among microbial species are usually determined by changes in moisture, sweat, menses and hormonal fluctuations ${ }^{19}$. Contaminant products such as panty liners may also have influence on vulvar environment characteristics. Runeman et al observed a mean skin temperature increase of $1.1^{\circ} \mathrm{C}$ as well as $\mathrm{pH}$ values significantly higher at labia majora and perineum in the presence of non-breathable panty liners when compared with the absence of panty liners ${ }^{20}$.

Resident vulvar microbiota consists of organisms which are characteristic to both cutaneous and vaginal environments ${ }^{21}$. Several studies have intended to determine and quantify the microbiology of human vulva, these studies have been summarized in table 1 (See table 1).

Aly et al reported relative proportions of bacteria at various sites on 18 individuals in the United States; vulvar microorganisms included coagulase-negative staphylococci (100\%), lipophilic diphtheroids (100\%) non-lipophilic diphtheroids (67\%), Lactobacilli (40\%), S. aureus (67\%) and Micrococci (56\%). Vulvar bacteria are noted in greater density and higher incidence when compared to other sites of the human body (such as forearm) ${ }^{18}$. Runeman et al examined the differences in microenvironment and biota between standard and string panty liners. Coagulase-negative staphylococci and Corynebacterium were the most prevalent microorganisms found in locations such as perineum, labia majora and panty liner (both regular and string) $)^{22}$. 
Vulvar samples taken from four healthy women recovered Lactobacillus crispatus and Lactobacillus iners as the most frequent bacterial organisms; 70.5 - $97 \%$ and $28.3-96.2 \%$ of these clones respectively, reported the same phylotype found in labia minora (23). Moreover, yeast species were not frequently isolated from genital areas ${ }^{23}$; Bentubo (2015), in a sample taken in Brazil, examined the presence of this organisms in genital regions, reportedly finding non-C. albicans candida yeasts and Candida parapsilosis as the most prevalent species ${ }^{24}$. Labia and groin tend to have more bacteria than other genital skin sites ${ }^{25}$. Lactobacillus spp was also reported as the predominant species by Miyamoto et al among healthy Japanese women, with Staphylococcus epidermidis likewise observed with a corresponding $98 \%, 100 \%$ and $95 \%$ of detection on labia and groin, mons pubis, and inner thigh, respectively ${ }^{25}$.

Table 1. Resident vulvar microbiota in women genitalia

\begin{tabular}{|c|c|c|c|c|c|c|c|c|c|c|c|c|}
\hline et al., (year) & 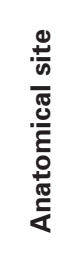 & 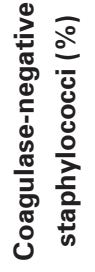 & 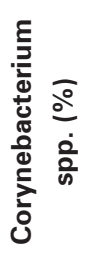 & 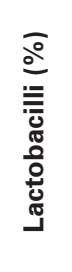 & 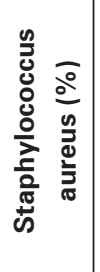 & 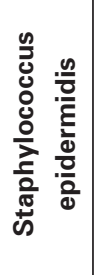 & 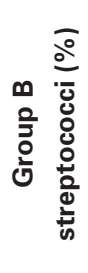 & 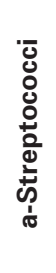 & 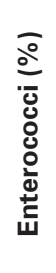 & 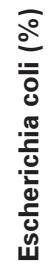 & $\begin{array}{l}\frac{n}{\bar{C}} \\
\frac{0}{0} \\
\frac{0}{\pi} \\
\frac{\pi}{0} \\
\frac{\pi}{0} \\
\frac{0}{0} \\
\frac{0}{\pi}\end{array}$ & 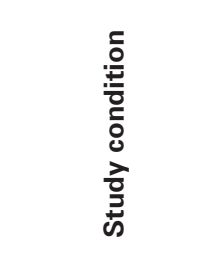 \\
\hline \multirow{6}{*}{$\begin{array}{l}\text { Runeman } \\
(2005)^{22}\end{array}$} & LMA & 100 & 97 & 100 & 13 & - & 34 & 53 & 13 & 9 & 12 & \multirow{3}{*}{$\begin{array}{c}\text { Regular panty } \\
\text { liner }\end{array}$} \\
\hline & PE & 97 & 100 & 100 & 25 & - & 41 & 63 & 19 & 41 & 16 & \\
\hline & $P L$ & 100 & 100 & 97 & 19 & - & 34 & 44 & 13 & 9 & 13 & \\
\hline & LMA & 100 & 100 & 100 & 10 & - & 19 & 52 & 13 & 19 & 10 & \multirow{3}{*}{$\begin{array}{l}\text { String panty } \\
\text { liner }\end{array}$} \\
\hline & $\mathrm{PE}$ & 100 & 100 & 100 & 23 & - & 32 & 61 & 19 & 45 & 10 & \\
\hline & PL & 100 & 100 & 100 & 13 & - & 26 & 42 & 16 & 23 & 13 & \\
\hline \multirow{9}{*}{$\begin{array}{l}\text { Runeman } \\
(2004)^{20}\end{array}$} & LMA & 99 & 91 & 99 & 12 & - & 28 & 29 & 30 & 13 & 12 & \multirow{3}{*}{ No panty liner } \\
\hline & PE & 97 & 92 & 97 & 13 & - & 38 & 32 & 34 & 47 & 15 & \\
\hline & PL & - & - & - & - & - & - & & - & - & - & \\
\hline & LMA & 100 & 94 & 96 & 10 & - & 33 & 29 & 34 & 19 & 8 & \multirow{3}{*}{$\begin{array}{c}\text { Non-breathable } \\
\text { panty liner }\end{array}$} \\
\hline & PE & 98 & 93 & 99 & 15 & - & 35 & 37 & 46 & 66 & 11 & \\
\hline & $\mathrm{PL}$ & 99 & 92 & 93 & 13 & - & 29 & 27 & 35 & 13 & 10 & \\
\hline & LMA & 98 & 92 & 96 & 11 & - & 34 & 26 & 33 & 18 & 5 & \multirow{3}{*}{$\begin{array}{c}\text { breathable, } \\
\text { acidic panty } \\
\text { liner }\end{array}$} \\
\hline & PE & 97 & 91 & 97 & 9 & - & 38 & 31 & 44 & 49 & 15 & \\
\hline & PL & 100 & 85 & 86 & 13 & - & 20 & 19 & 22 & 7 & 6 & \\
\hline $\begin{array}{c}\text { R.Aly } \\
(1979)^{18} \\
\end{array}$ & VV & 100 & - & 40 & 67 & - & - & & - & - & - & $\begin{array}{c}\text { Clinically } \\
\text { normal women }\end{array}$ \\
\hline \multirow{3}{*}{$\begin{array}{c}\text { Miyamoto } \\
(2013)^{25}\end{array}$} & LG & - & - & 85 & 63 & 98 & - & - & - & - & - & \multirow{3}{*}{$\begin{array}{l}\text { Healthy } \\
\text { Japanese } \\
\text { women }\end{array}$} \\
\hline & MP & - & - & 70 & 45 & 100 & - & - & - & - & - & \\
\hline & IT & - & - & 65 & 50 & 95 & - & - & - & - & - & \\
\hline
\end{tabular}

Source: authors

The microbial organisms of the labia majora are significantly different from those found inside the vagina ${ }^{26}$. The normal microbiota of the vagina mainly consists of Lactobacillus crispatus, Lactobacillus gasseri, Lactobacillus jensenii and Lactobacillus iners $^{27}$. The importance of Lactobacillus spp. relies on its ability to produce lactic acid (by glycogen conversion) contributing to its enhanced acidic $\mathrm{pH}$, thus protecting the growth of potential pathogens. Yeast cells (Mycoplasma and Ureaplasma species) may also colonized up to $20 \% 27$. 
Septiembre - Diciembre

Changes of female genital skin microenviroment: menses and experience with Herpes virus type 2 seropositive patients

The microbiota of the human vulva is complex and unique $^{23}$, constant influences, both internal (vaginal fluid and menstruation) and external (urine and fecal material) may affect its microbial type-diversity ${ }^{26}$. Molecular methods have been developed to identify the microbial community of the genital region. Reports from healthy Japanese women showed that the most abundant phylotypes in the labia minora were most similar to either Lactobacillus crispatus or L. iners. In addition L. crispatus or L. iners were also the predominant bacteria on the labia minora at premenstruation period and clones similar to L. crispatus were predominant at both premenstruation and during menstruation ${ }^{26}$. A previous study by Lansdell et al., intended to recover S. aureus from the external labia and tampons at the time of menstruation; a total of $7.2 \%$ of S. aureus were recovered on labia ${ }^{28}$.

Löwhagen et al assessed microbiota in the vulvar skin between Herpes virus type 2 seropositive patients with and without clinical recurrences which showed a tendency towards more lactobacilli and $E$. coli on the labia majora in the asymptomatic group ${ }^{29}$; moreover, coagulase-negative Staphylococci appeared to be the most frequent sampled microorganism (See table 2).

\begin{tabular}{|c|c|c|c|c|c|c|c|c|c|c|}
\hline $\begin{array}{l}\text { Author } \\
\text { (year) }\end{array}$ & 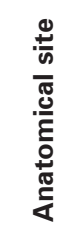 & 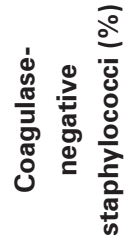 & 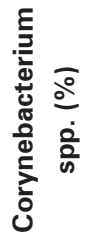 & 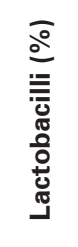 & 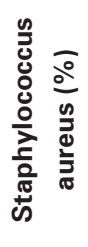 & 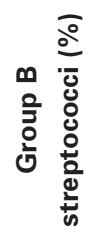 & 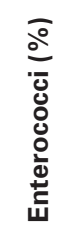 & 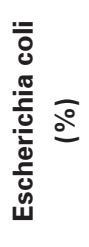 & 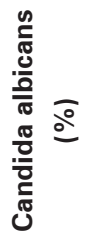 & 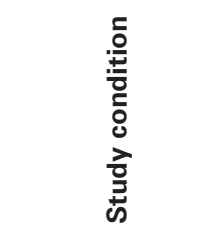 \\
\hline \multirow{2}{*}{ Löwhagen } & LMA & 100 & 100 & 60 & 10 & 40 & 20 & 20 & 10 & \multirow{2}{*}{$\begin{array}{c}\text { HSV-2 } \\
\text { symptomatics }\end{array}$} \\
\hline & PE & 100 & 100 & 88,9 & 22,2 & 55,6 & 20 & 22,2 & 11,1 & \\
\hline \multirow[t]{2}{*}{ et al $(2006)^{29}$} & LMA & 100 & 63,6 & 72,7 & 0 & 45,5 & 63,6 & 9,1 & 9,1 & \multirow{2}{*}{$\begin{array}{c}\text { HSV-2 } \\
\text { Asymptomatics }\end{array}$} \\
\hline & $\mathrm{PE}$ & 100 & 63,6 & 81,8 & 0 & 45,5 & 54,5 & 45,5 & 9,1 & \\
\hline
\end{tabular}

Source: authors

\section{Genital hair removal: side effects and health concerns}

Pubic hair is anatomically structured by cortex and cuticle cells, hair follicle and sebaceous glands. It is the heavier, longer hair that develops during puberty ${ }^{30}$. These structures form a microenvironment of their own, which supports the establishment of an unique and characteristic microbiota in the pubic hair. Among the most distinctive taxa found are Corynebacterium, Staphylococcus, Finegoldia, and Micrococcus. Other studies have found abundance of Lactobacillus ${ }^{31}$. Evidence has suggested that there are differences in the bacterial composition between individuals. Tridico et al., found clear distinctions between male and female pubic hairs, which is mainly explained by the prevalence of Lactobacillus spp in women's pubic hair in contrast with, a taxa that wasn't found in men's samples. However, they also observed that cross-transference of microbial pubic taxa could occur as a result of intercourse, affecting the variation in microbiota and similarities between partners ${ }^{32}$.

Extensive hair removal leads a risk of hair microtrauma, vulvovaginal irritation (especially due to shaving) and potential spread of infectious agents throughout the pubic area ${ }^{19}$.

Infections associated to barrier impairments in activities such as sexual intercourse were reported in a study including 61 patients, Molluscum contagiosum was found in $71 \%$ and Human Papilloma virus in $11 \%$ 33,34 . Herpes virus has been found in $2-4 \%$ of patients with grooming practices. This is commonly explained by an epidermis impairment, that facilitates the penetration and dissemination of these entities 35,36 . 
Some authors have suggested the introduction of pubic hair removal and the positive rate of Phthirus pubis infestation ${ }^{34}$; by contrast, recent observations have also suggested pubic hair as a preventive procedure against $P$. pubis, arguing that eradication of pubic lice (by pubic hair removal) may destroy the parasite habitat.

In addition, women who are admitted to a hospital to give childbirth may receive perineal shaving. It is believed that this measure reduces the risk of infection caused by spontaneous perineum tear or if an episiotomy is performed, consequently making episiorrhaphy easier as well as aiding with instrumental deliveries ${ }^{37}$. However, when viewed over overall anatomical wounds (not only genital or perineal) previous studies have also appointed this measure as potentially deleterious. A 10-year prospective study of 62,939 wounds appointed perineal shaving as methods that increased the infection rate of clean wounds ${ }^{38}$. In a more specific view of perineal shaving versus no perineal shaving, Johnson and Sidall, in 1922, compared skin preparation and perineal shaving as the control variable, and clipping of vulvar hair only as the experimental variable, with the primary outcome being febrile puerperium (if an elevation of 100.4" or above occurred on two successive days, excluding the day of delivery); no significant differences were found between both preparations ${ }^{39}$. There is little evidence to suggest that perineal shaving benefits women entering child labor and clinical significance of the difference in women having Gram-negative bacteria is sparse ${ }^{37}$. Although more investigations are needed to stablish links between genital hair removal and de novo infections or recurrences, it is possible that complete removal of pubic hair, being the physical barrier for the vulvovaginal area, could lead to increase susceptibility to infections ${ }^{34}$.

\section{Conclusions}

Genital hair removal has a noteworthy effect on genital skin microenvironment; skin lesions and microbiota disturbances are prone to shortand long-term clinical significance. Considerable progress has been made in the understanding of the changes responsible for morbidity in the context of microenvironment impairment associated with genital hair removal. In the context of skin barrier changes in microbiota, hair removal may lead to possible infections, especially when activities such as sexual intercourse are taking place where
Herpes type 2, Human Papilloma Virus and Molluscum contagiosum may play a role. Determining the precise microbiota changes due to this practice and its role in general microenvironment changes, represents an important clinical and scientific challenge, since overall knowledge does not consider the possible side effects of this common practice, and future recommendations may be developed in order to maintain female skin microbioma balance.

\section{References}

1. Díaz-Martínez LA. Contextualización histórica y social de la remoción del vello púbico femenino. Rev Colomb Obstet Ginecol. 2013;64(4):453-61.

2. Ramsey S, Sweeney C, Fraser M, Oades G. Pubic hair and sexuality: a review. J Sex M. 2009;6(8):2102-10.

3. Riddell L, Hodgson HG, Varto H. Smooth talking: the phenomenon of pubic hair removal in women. Can J Hum Sex. 2010;19(3):12130.

4. ClinicalTrials.gov [Internet]. Bethesda (MD): National Library of Medicine (US). 2000 Feb 29 - . Identifier NCT03272204, Pubic hair and the urinary and vaginal microbiome; 2017 Aug 18. Disponible en: https://clinicaltrials.gov/ct2/show/NCT03272204.

5. Terry G, Braun V. To let hair be, or to not let hair be? Gender and body hair removal practices in Aotearoa/New Zealand. Body Image. 2013;10(4):599-606.

6. Díaz-Martínez LA, Durán-Prada ML, Mendoza-Pedrozo JP. La remoción por estética del vello púbico como causa de morbilidad inadvertida en la población general. Rev Argent Dermatol. 2015;96(3):40-6.

7. Díaz-Martínez LA, Prince NE, Barrera L, Hernández NA, Méndez DJ, Acevedo M. Prevalencia de la remoción del vello púbico en Colombia. Rev Argent Dermatol [Internet]. 2016;97(2):16-23. Disponible en: https://rad-online.org.ar/2016/07/01/prevalenciade-la-remocion-del-vello-pubico-en-colombia/

8. Herbenick D, Hensel D, Smith NK, Schick V, Reece M, Sanders SA, et al. Pubic hair removal and sexual behavior: Findings from a prospective daily diary study of sexually active women in the United States. J Sexual Med [Internet] . 2013;10(3):678-85. Doi: doi.org/10.1111/jsm.12031

9. DeMaria AL, Flores M, Hirth JM, Berenson AB. Complications related to pubic hair removal. Am J Obstet Gynecol [Internet] . 2014;210(6):528.e1-5.Disponible en: https:/www.ncbi.nlm.nih. gov/pmc/articles/PMC4040320/

10. Abdallah F, Mijouin L, Pichon C. Skin immune landscape: Inside and outside the organism. Mediat Inflammat [Internet]. 2017;2017:1-17. Doi: doi.org/10.1155/2017/509529.

11. Elsner P, Wilhelm D, Maibach HI. Mechanical properties of human forearm and vulvar skin. $\mathrm{Br} \mathrm{J}$ Dermatol [Internet]. 1990;122(5):607-14. Doi: doi.org/10.1111/j.1365-2133.1990. tb07282.x

12. Schommer NN, Gallo RL. Structure and function of the human skin microbiome. Trends Microbiol [Internet]. 2013;21(12):660-8. Doi:doi.org/10.1016/j.tim.2013.10.001.

13. Williams DW, Gibson G. Individualization of pubic hair bacterial communities and the effects of storage time and temperature. Forensic Sci Int Genet. 2017;26:12-20. doi: 10.1016/j. fsigen.2016.09.006

14. Zeeuwen PL, Kleerebezem M, Timmerman HM, Schalkwijk J. Microbiome and skin diseases. Curr Opin Allergy Clin Immunol. 2013;13(5):514-20. doi: 10.1097/ACI.0b013e328364ebeb

15. Soria X, Carrascosa JM. Flora cutánea normal e infección bacteriana secundaria. Actas Dermosifiliogr. 2007;98(1):15-21. https://doi.org/10.1016/S0001-7310(07)70177-1

16. Nakamizo S, Egawa G, Honda T, Nakajima S, Belkaid Y, Kabashima K. Commensal bacteria and cutaneous immunity. Semin Immunopathol. 2015;37(1):73-80. doi: 10.1007/s00281014-0452-6

17. Brandwein M, Steinberg D, Meshner S. Microbial biofilms 


\section{Septiembre - Diciembre}

and the human skin microbiome. NPJ Biofilms Microbiome. 2016;2(3):1-6. doi: 10.1038/s41522-016-0004-z

18. Aly R, Britz MB, Maibach HI. Quantitative microbiology of human vulva. Br J Dermatol. 1979;101(4):445-8. doi: 10.1111/ j.1365-2133.1979.tb00024.x

19. Chen Y, Bruning E, Rubino J, Eder SE. Role of female intimate hygiene in vulvovaginal health: Global hygiene practices and product usage. Womens Health (Lond). 2017;13(3):58-67.

20. Runeman B, Rybo G, Forsgren-Brusk U, Larkö O, Larsson P, Faergemann J. The vulvar skin microenvironment: Influence of different panty liners on temperature, $\mathrm{pH}$ and microflora. Acta Derm Venereol. 2004;84(4):277-84.

21. Wilson M. The indigenous microbiota of the reproductive system of females. In: Wilson M. Bacteriology of humans: An ecological perspective. USA: Blackwell Publishing; 2008. p. 170-206.

22. Runeman B, Rybo G, Forsgren-Brusk U, Larkö O, Larsson P, Faergemann J. The vulvar skin microenvironment: ompact of tight-fitting underwear on microclimate, $\mathrm{pH}$ and microflora. Acta Derm Venereol. 2005;85(2):118-22.

23. Brown CJ, Wong M, Davis CC, Kanti A, Zhou X, Forney LJ. Preliminary characterization of the normal microbiota of the human vulva using cultivation-independent methods. J Med Microbiol. 2007;56(2):271-6.

24. Bentubo HDL, Mantovani A, Yamashita JT, Gambale W, Fischman O. Yeasts of the genital region of patients attending the dermatology service at Hospital São Paulo, Brazil. Rev Iberoam Micol. 2015;32(4):229-34.

25. Miyamoto T, Akiba S, Sato N, Fujimura T, Takagi Y, Kitahara $\mathrm{T}$, et al. Study of the vulvar skin in healthy Japanese women: Components of the stratum corneum and microbes. Int J Dermatol. 2013;52(12):1500-5.

26. Aramaki J, Kawana S, Effendy I, Happle R, Loffler H. Differences of skin irritation between Japanese and European women. Br J Dermatol. 2002;146(6):1052-6.

27. Dasari S, Anandan SK, Rajendra W, Valluru L. Role of microbial flora in female genital tract: A comprehensive review. Asian Pacific J Trop Dis. 2016;6(11):909-17.

28. Lansdell LW, Taplin D, Aldrich TE. Recovery of Staphylococcus aureus from multiple body sites in menstruating women. J Clin Microbiol. 1984;20(3):307-10.

29. Löwhagen GB, Bonde E, Forsgren-Brusk U, Runeman B, Tunbäck P. The microenvironment of vulvar skin in women with symptomatic and asymptomatic herpes simplex virus type 2 (HSV2) infection. J Eur Acad Dermatol Venereol. 2006;20(9):1086-9.

30. Buffoli B, Rinaldi F, Labanca M, Sorbellini E, Trink A, Guanziroli E, et al. The human hair: From anatomy to physiology. Int J Dermatol. 2014;53(3):331-41

31. Brinkac L, Clarke TH, Singh H, Greco C, Gomez A, Torralba MG, et al. Spatial and environmental variation of the human hair microbiota. Sci Rep. 2018;8(1):9017.

32. Tridico SR, Murray DC, Addison J, Kirkbride KP, Bunce M. Metagenomic analyses of bacteria on human hairs: A qualitative assessment for applications in forensic science. Investig Genet. 2014;5(1):16.

33. Veraldi S, Nazzaro G, Ramoni S. Pubic hair removal and molluscum contagiosum. Int J STD AIDS. 2016;27(8):699-700.

34. Veraldi S, Schianchi R, Ramoni S, Nazzaro G. Pubic hair removal and Phthirus pubis infestation. Int J STD AIDS. 2018;29(1):103-4.

35. Desruelles F, Cunningham SA, Dubois D. Pubic hair removal: A risk factor for 'minor' STI such as molluscum contagiosum? Sex Transm Infect. 2013;89(3):216-216.

36. Osterberg EC, Gaither TW, Awad MA, Truesdale MD, Allen I, Sutcliffe S, et al. Correlation between pubic hair grooming and STIs: Results from a nationally representative probability sample. Sex Transm Infect. 2017;93(3):162-6.

37. Basevi V, Lavender T. Routine perineal shaving on admission in labour. CDSR [Internet]. 2014 [May 12th, 2018]; 11: Pages: 1-22. Disponible en: http://doi.wiley.com/10.1002/ 14651858. CD001236.pub2.

38. Cruse PJE, Foord R. The epidemiology of wound infection: A 10-Year prospective study of 62,939 wounds. Surg Clin N Am. 1980;60(1):27-40

39. Johnston RA, Sidall RS. Is the usual method of preparing patients for delivery beneficial or necessary? Am J Obstet Gynecol. 1922;4(6):645-50. 